Jurnal Teknik Komputer AMIK BSI

Volume 8, No.1, Januari 2022

P-ISSN 2442-2436, E-ISSN: 2550-0120

Akreditasi Ristekdikti, No: 36/E/KPT/2019 (Sinta 4)

DOI: $10.31294 /$ jtk.v4i2

\title{
Implementasi Model Waterfall Pada Pembangunan Sistem Informasi Keuangan Proyek
}

\author{
Riska Aryanti ${ }^{1}$, Diah Puspitasari ${ }^{2}$, Rachilsyah Ramdhani Efendi ${ }^{3}$, Rizqi Nur Esmeralda ${ }^{4}$ \\ 1,2,3,4 Universitas Bina Sarana Informatika \\ 1riska.rts@bsi.ac.id \\ ${ }^{2}$ diah.puspitasari@bsi.ac.id \\ ${ }^{3}$ rachilsyah@gmail.com \\ ${ }^{4} 15200349 @$ bsi.ac.id

\begin{tabular}{ccc}
\hline Diterima & Direvisi & Disetujui \\
$24-12-2021$ & $03-01-2022$ & $07-01-2022$ \\
\hline
\end{tabular}

\begin{abstract}
Abstrak - Diera digital seperti sekarang ini, teknologi berkembang sangat pesat. Komputer sudah menjadi kebutuhan utama dalam proses bisnis di masa sekarang. PT Suma Karya Gemilang adalah sebuah perusahaan yang bergerak di bidang konstruksi. PT Suma Karya Gemilang dalam menjalankan bisnisnya masih belum terkomputerisasi seperti pengajuan dana dan pembuatan laporan pengeluaran proyek. Dampak Sistem yang belum terkomputerisasi menyebabkan tidak efektifnya dalam bekerja, sering terjadinya kesalahan yang tidak disengaja, sering terjadinya penumpukan dokumen yang belum diproses sehingga mengakibatkan dokumen mudah hilang dan rusak jika tidak diproses dengan cepat, pembuatan laporan pengeluaran proyek sering kali terjadi kesalahan penulisan dan tidak akurat dalam pembuatannya. Sehingga perancangan sistem informasi keuangan proyek dengan metode pengembangan Waterfall adalah solusi permasalahan yang ada di PT Suma Karya Gemilang. Dengan sistem yang terkomputerisasi dengan proses kerja menjadi lebih efisien dan efektif dalam menunjang segala aktivitas perusahaan. Hasil yang diperoleh dengan menggunakan sistem yang terkomputerisasi mengurangi kesalahan penulisan, pembuatan laporan menjadi akurat dan efektif, dengan penggunaan basis data dokumen menjadi lebih teratur dan tidak menumpuk. Secara keseluruhan dengan sistem yang terkomputerisai jauh lebih baik dari segala aspek dari pada sistem yang belum terkomputerisasi.
\end{abstract}

Kata Kunci: Sistem Informasi Berbasis Web, Keuangan Proyek, Waterfall

\begin{abstract}
In the digital era like today, technology is developing very rapidly. Computers have become a major requirement in business processes today. PT Suma Karya Gemilang is a company engaged in the construction sector. PT Suma Karya Gemilang in running its business is still not computerized such as submitting funds and making project expense reports. The impact of a system that has not been computerized causes ineffectiveness in work, frequent unintentional errors, frequent buildup of unprocessed documents, resulting in documents being easily lost and damaged if not processed quickly, making project expense reports often writing errors and inaccurate in the making. So that the design of a project financial information system with the Waterfall development method is a solution to the problems that exist at PT Suma Karya Gemilang. With a computerized system, the work process becomes more efficient and effective in supporting all company activities. The results obtained by using a computerized system reduce writing errors, report generation becomes accurate and effective, with the use of document databases becoming more organized and not piling up. Overall, a computerized system is much better in all aspects than a non-computerized system.
\end{abstract}

Keywords: Web-Based Information Systems, Project Finance, Waterfall

\section{PENDAHULUAN}

Pertumbuhan industri konstruksi ini membuat persaingan antar perusahaan semakin ketat karena semakin banyaknya minat perusahaan yang ingin masuk dalam industri konstruksi. Persaingan yang ketat membuat suatu perusahaan harus dapat mengerjakan suatu proyek konstruksi dengan manajemen yang baik agar waktu yang ditetapkan dapat sesuai dengan waktu pengerjaannya.

Perusahaan tidak ketat dalam mengelola data keuangan sehingga seringkali kehilangan beberapa 
dokumen transaksi dan menyebabkan jumlah uang di perusahaan dengan jumlah uang dalam catatan keuangan berbeda. Setiap bulan perusahaan hanya membuat laporan laba rugi dan memperkirakan besarnya laba tanpa perhitungan yang akurat karena transaksi kecil tidak tercatat (Lesmana et al., 2020). PT Suma Karya Gemilang adalah sebuah perusahaan yang bergerak di bidang pelayanan konstruksi mencakup renovasi, bangun baru, interior dan pembuatan produk furniture untuk rumah tinggal, apartemen, gedung perkantoran, ruko, restoran, gudang, serta pabrik. Dalam pengelolaan data yang ada, PT Suma Karya Gemilang masih menggunakan penyimpanan data keuangan yang belum terkomputerisasi sehingga untuk mencari data keuangan proyek yang telah dilakukan sedikit memakan waktu lama. Pengajuan dana yang masih ditulis, pencairan dana yang sering kali terlambat, pembelian barang yang sering tidak terdokumentasi dengan baik, dan juga kesalahan pencatatan dalam proses pembuatan laporan pengeluaran proyek. Dengan diterapkannya sistem yang berjalan saat ini beresiko terjadinya tindakan manipulasi data karena pencatatan laporan yang masih belum terkomputerisasi sehingga tingkat keamanannya rendah, juga hasil yang didapat cenderung lambat dan kurang akurat.

Berdasarkan masalah diatas penulis menganalisa kebutuhan apa saja yang dibutuhkan user untuk membantu pengajuan dana untuk operasional proyek, pencairan dana, sampai dengan pembuatan laporan pengeluaran proyek. Sehingga membuatkan suatu aplikasi berbasis website yang dapat mengatasi permasalahan yang ada serta menerapkan metode waterfall sebagai model yang akan digunakan untuk merancang aplikasi berbasis web yang akan dibuat.

\section{A. Sistem Informasi}

Sistem informasi adalah suatu sistem di dalam suatu organisasi yang mempertemukan kebutuhan pengolahan transaksi harian yanmg mendukung fungsi operasi organisasi yang bersifat manajerial dengan kegiatan strategi dari suatu organisasi untuk dapat menyediakan kepada pihak luar tertentu dengan laporan-laporan yang diperlukan(Andrianto \& Nursikuwagus, 2017).

\section{B. Website}

Website merupakan kumpulan halaman digital yang berisi informasi berupa teks, animasi, gambar, suara dan video atau gabungan dari semuanya yang terkoneksi oleh internet, sehingga dapat dilihat oleh seluruh siapapun yang terkoneksi jaringan internet(Sari et al., 2019).

Website dapat diartikan sebagai kumpulan halamanhalaman yang digunakan untuk mempublikasikan informasi berupa teks, gambar, dan program multimedia lainnya berupa animasi (gambar gerak, tulisan gerak), suara atau gabungan dari semuanya itu baik yang bersifat statis maupun dinamis yang membentuk satu rangkaian bangunan yang saling terkait antara atu halaman dengan halaman yang lainnya yang sering disebut hyperlink(Marisa, 2017).

\section{Web Server}

Web server merupakan perangkat lunak yang berfungsi untuk menerima permintaan (request) melalui protokol HTTP atau HTTPS dari client kemudian mengirimkan kembali dalam bentuk halaman-halaman web(Abdulloh, 2018).

\section{Internet}

Internet atau interconnected networking merupakan dua komputer atau lebih yang saling berhubungan membentuk jaringan komputer hingga meliputi jutaan komputer di dunia, yang saling berinteraksi dan bertukar informasi(Durahman \& Karma, 2018).

\section{E. Proyek}

Proyek adalah suatu kegiatan yang dilakukan dengan waktu dan sumber daya terbatas untuk mencapai hasil akhir yang ditentukan. Dalam mencapai hasil akhir, kegiatan proyek dibatasi oleh anggaran, jadwal, dan mutu, yang dikenal sebagai tiga kendala (triple constraint). (Rani, 2016).

\section{F. Proyek Konstruksi}

Proyek konstruksi merupakan suatu rangkaian kegiatan yang hanya satu kali dilakukan dan umumnya berjangka pendek. Dalam rangkaian kegiatan tersebut, terdapat suatu proses yang mengolah sumber daya proyek menjadi suatu hasil kegiatan yang berupa bangunan(Refun et al., 2017).

\section{G. Manajemen Proyek}

Manajemen Proyek adalah suatu penerapan ilmu pengetahuan, keahlian dan juga ketrampilan, cara teknis yang terbaik serta dengan sumber data yang terbatas untuk mencapai sasaran atau tujuan yang sudah ditentukan agar mendapatkan hasil yang optimal dalam hal kinerja, waktu, mutu dan keselamatan kerja(Sitanggang et al., 2019).

\section{H. Manajemen Biaya Proyek}

Manajemen Biaya Proyek meliputi proses-proses yang terlibat dalam perencanaan, estimasi, penganggaran, pembiayaan, pendanaan, pengelolaan, dan pengendalian biaya sehingga proyek dapat diselesaikan dalam anggaran yang telah disetujui(Simanjuntak \& Baskoro, 2020).

\section{METODOLOGI PENELITIAN}

Metodologi pada penelitian ini adalah sebagai berikut:

\section{Teknik Pengumpulan Data}

Pengumpulan data dapat diartikan sebagai proses atau kegiatan yang dilakukan untuk mengungkap atau mendapatkan berbagai informasi atau kondisi 
lokasi penelitian sesuai dengan lingkup penelitian. Pengumpulan data juga bisa diartikan sebagai sebagai proses yang menggambarkan pengumpulan data secara kuantitatif dan kualitatif, beberapa teknik yang digunakan dalam mengumpulkan data yaitu:

a. Observasi

Pada tahapan ini penulis melakukan pengamatan secara langsung dan penelitian langsung pada objek penelitian, dengan mengamati dan memperhatikan langsung proses sistem pengelolaan keuangan proyek di PT Suma Karya Gemilang.

b. Wawancara

Pada tahapan ini penulis mengajukan pertanyaan yang di jawab langsung oleh bapak Toni Gunanto di PT Suma Karya Gemilang. Bertanya secara langsung bagaimana sistem pengelolaan keuangan proyek yang berjalan.

c. Studi Pustaka

Pada tahapan ini penulis mengacu pada bukubuku pedoman yang dibutuhkan untuk menunjang penulisan dan menjadi referensi penelitian serta jurnal-jurnal lain yang berkaitan dengan tema yang penulis teliti .

\section{Teknik Pengembangan Sistem}

Metode yang digunakan sebagai dasar untuk menentukan pembuatan aplikasi berdasarkan model pengembangan perangkat lunak yaitu model air terjun (Waterfall). "Model air terjun menyediakan pendekatan alur hidup perangkat lunak secara sekuensial atau terurut dimulai dari analisis, desain, pengodean, pengujian dan tahap pendukung (support)"(Sukamto \& Shalahuddin, 2019). Adapun langkah-langkah metode air terjun (waterfall) menurut (Sukamto \& Shalahuddin, 2019) yaitu:

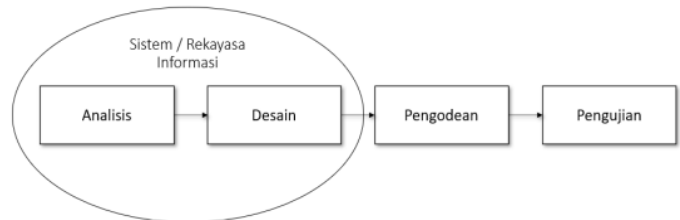

Sumber: (Sukamto \& Shalahuddin, 2019)

Gambar 1

Ilustrasi Model Waterfall

a. Analisis kebutuhan perangkat lunak

Pada proses ini penelitian dilakukan secara insentif untuk mengetahui kebutuhan perangkat lunak seperti apa yang dibutuhkan oleh user. Spesifikasi kebutuhan perangkat lunak pada tahap ini perlu untuk didokumentasikan.

b. Desain

Desain perangkat lunak adalah tahapan yang fokus pada desain pembuatan program perangkat lunak termasuk arsitektur perangkat lunak, struktur data, prosedur pengkodean dan representasi antarmuka, Tahap ini merepresentasikan kebutuhan perangkat lunak dari tahap kebutuhan sistem ke representasi desain sehingga pada tahap selanjutnya dapat diimplementasikan menjadi program dan desain yang dihasilkan pada tahap ini perlu didokumentasikan.

c. Pembuatan kode program

Setelah tahapan desain harus ditransformasikan ke dalam program perangkat lunak, sehingga hasil dari tahap ini adalah suatu program komputer yang sesuai dengan desain yang telah dibuat pada tahap desain.

\section{d. Pengujian}

Tahapan ini memastikan bertujuan untuk memastikan semuan fungsi sistem dapat bekerja dengan baik dan mencari kesalahan yang terjadi pada sistem yang telah dibuat sehingga fokus peneliti pada perangkat lunak berasal dari segi fungsional dan logic serta memastikan bahwa semua bagian sudah diuji, hal ini dilakukan untuk meminimalisir kesalahan (error) dan output yang dihasilkan sudah sesuai dengan yang diinginkan.

e. Pendukung (support) atau pemeliharaan (maintenance)

Tahapan yang terakhir ini memungkinkan sebuah aplikasi mengalami perubahan saat telah dikirimkan ke user. Perubahan terjadi karena adanya kesalahan yang ada serta tidak terdeteksi saat pengujian atau aplikasi harus beradaptasi dengan lingkungan baru. tahap pendukung atau pemeliharaan bisa mengulangi proses pengembangan mulai dari analisis spesifikasi untuk perubahan aplikasi yang telah ada, namun tidak untuk menghasilkan software baru.

\section{HASIL DAN PEMBAHASAN}

\section{Analisis Kebutuhan Perangkat Lunak}

a. Pengajuan pembelian barang

Pertama-tama pelaksana lapangan mensurvey lokasi proyek dan mencatat bahan-barang material bangunan apa yang dibutuhkan kemudian mencari berapa harganya. Kedua meminta form petty cash kepada admin keuangan dan mengisi form petty cash tersebut dengan barang material yang ingin dibeli. Ketiga memberikan form petty cash itu kembali kepada admin keuangan yang kemudian akan memeriksa form itu jika sudah benar maka akan dibawa ke direktur untuk menandatangani dan menyetujui. Terakhir admin keuangan akan memberikan sejumlah uang yang disetujui sesuai form petty cash kepada pelaksana lapangan melalui transfer bank dan menyimpan bukti transfer dan form petty cash yang sudah disetujui akan diberikan kepada pelaksana lapangan.

b. Pembelian material bangunan

Pelaksana lapangan akan membeli barang sesuai yang ada di form petty cash di toko bangunan. Selanjutnya yaitu pelaksana lapangan melakukan pembayaran dan 
menerima nota pembayaran sebagai bukti pembayaran. Ketiga ketika barang sudah diterima kemudian pelaksana lapangan akan memberikan kepada pekerja untuk melanjutkan pengerjaan proyek.

c. Laporan pengeluaran proyek

Pelaksana lapangan akan membuat laporan pengeluaran proyek dan mengisi barang material apa yang sudah dibeli dan berapa harganya dan juga melampirkan form petty cash dan nota pembelian untuk membuktikan bahwa transaksi benar-benar ada jika sudah selesai kemudian memberikan laporan pembelian kepada admin keuangan. Kedua admin keuangan akan memeriksa laporan pembembelian jika laporan pembelian sudah sesuai dengan di form petty cash dan di nota pembelian, kemudian admin keuangan akan memeriksa dan melampirkan bukti transfer kemudian menyetujuinya dan memberikan laporan pengeluaran proyek kepada direktur.

\section{1) Use Case Diagram}

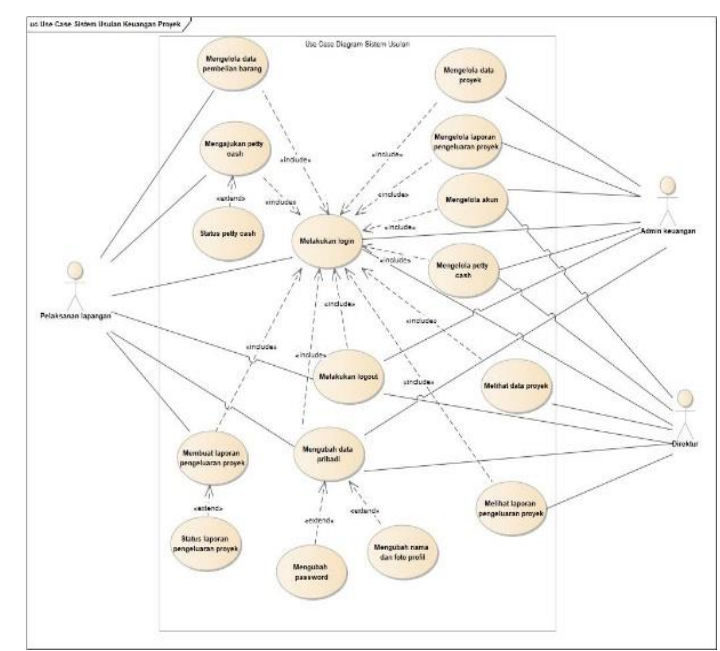

Sumber : Penelitian (2021)

Gambar 2

Use Case Diagram
2) Activity diagram

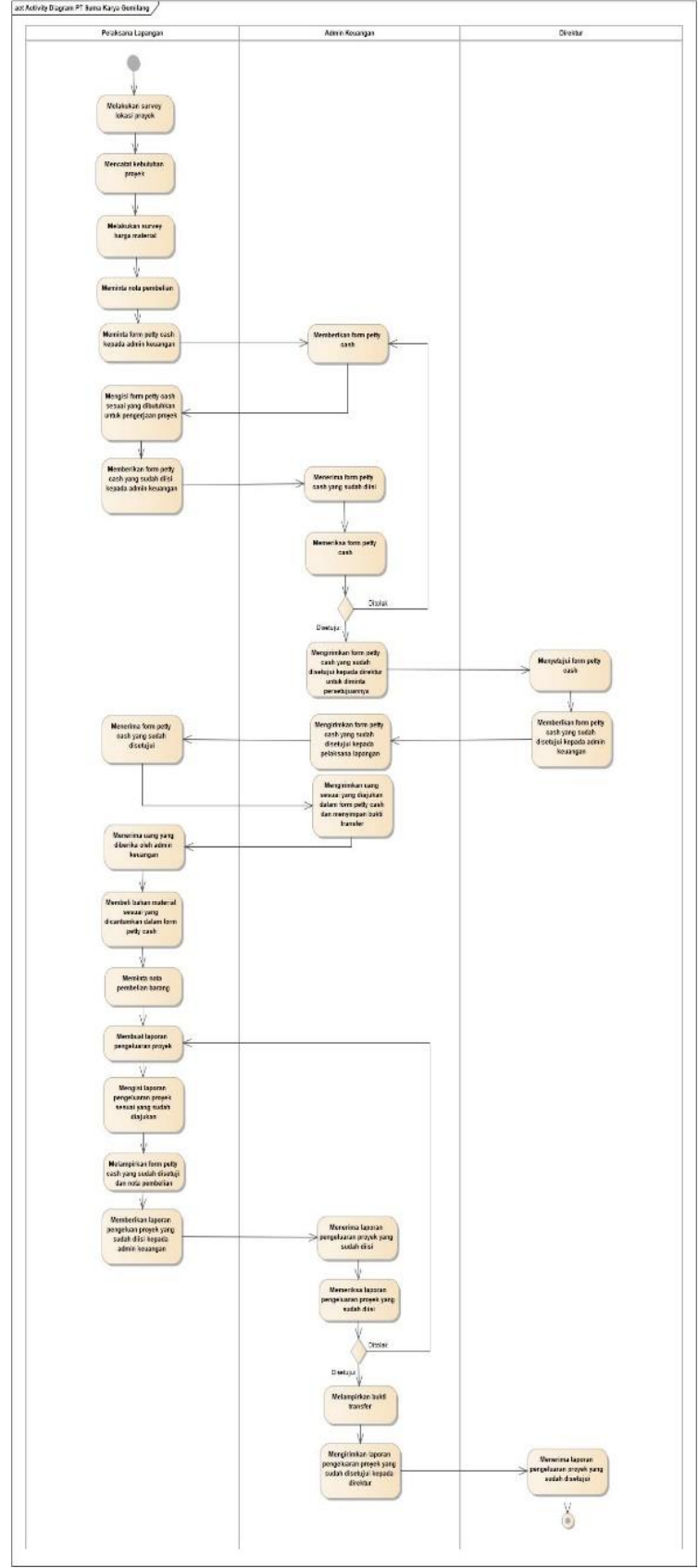

Sumber : Penelitian (2021)

Gambar 3

Activity Diagram 


\section{Design}

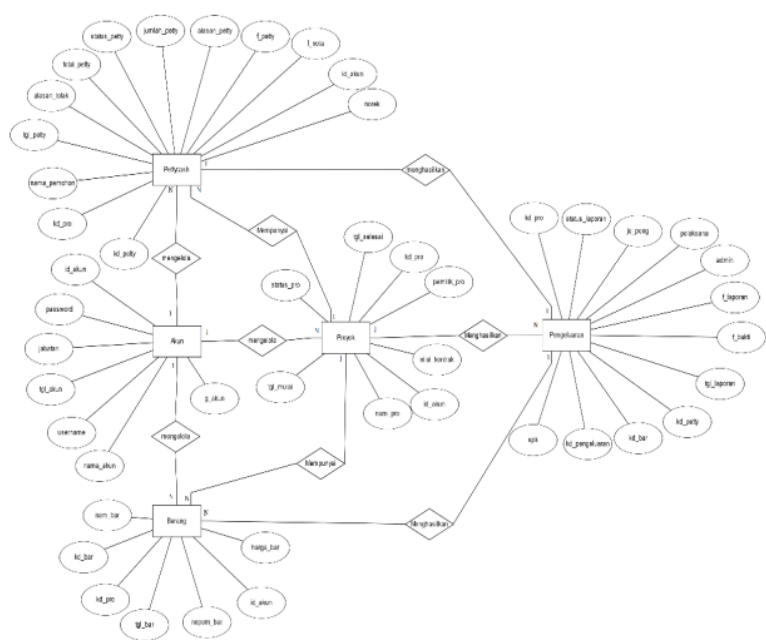

Sumber : Penelitian (2021)

Gambar 4

Entity Relationship Diagram (ERD)

\section{Implementasi (Implementation)}

\section{a. Halaman login}
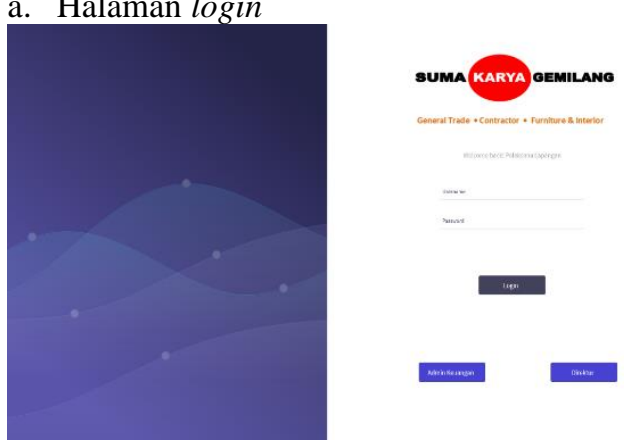

Sumber : Penelitian (2021)

Gambar 5

Halaman login

\section{b. Halaman utama}

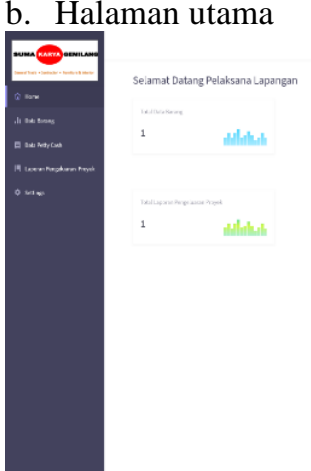

Sumber : Penelitian (2021)

Gambar 6

Halaman utama

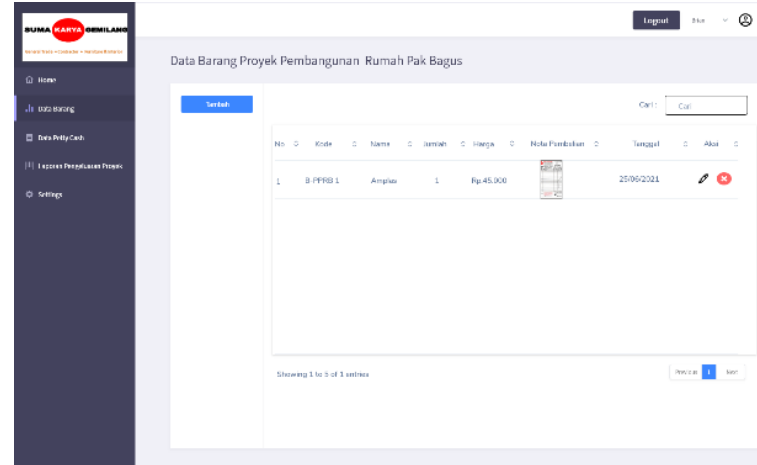

Sumber : Penelitian (2021)

Gambar 7

Halaman data barang

d. Halaman data petty cash

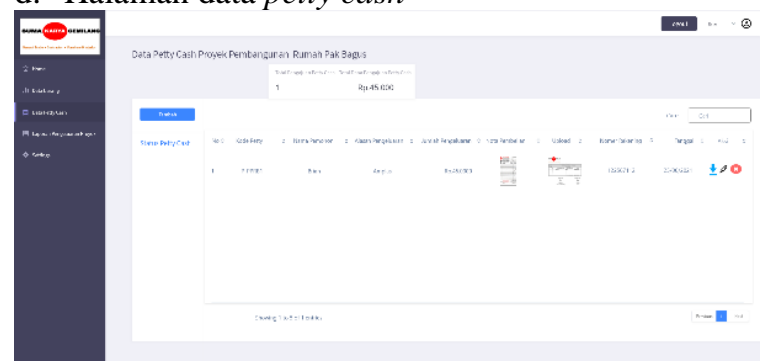

Sumber : Penelitian (2021)

Gambar 8

Halaman data petty cash

e. Halaman status petty cash

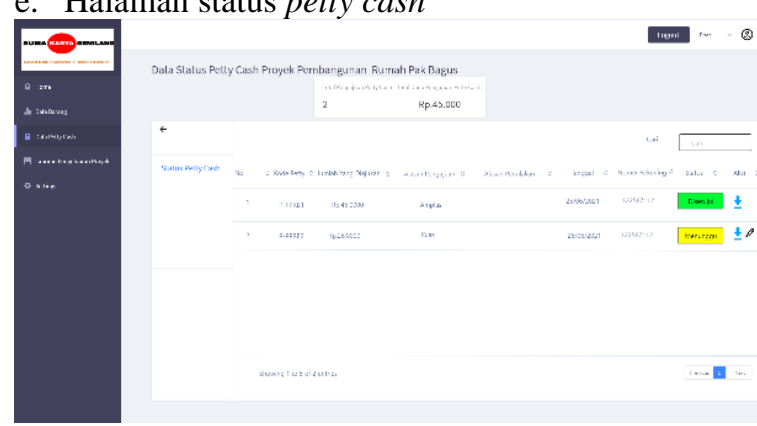

Sumber : Penelitian (2021)

Gambar 9

Halaman status petty cash

f. Halaman laporan pengeluaran proyek

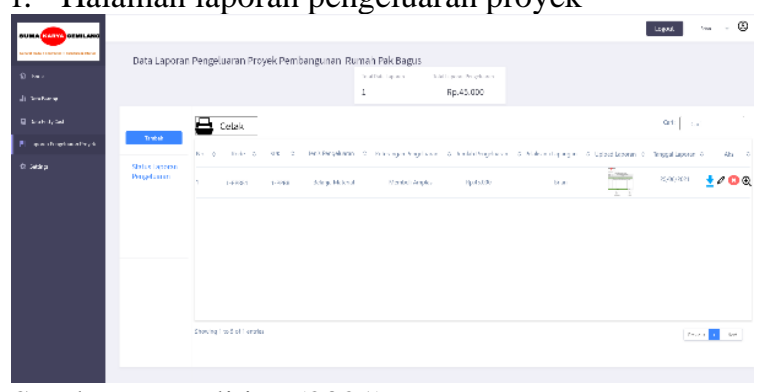

Sumber : Penelitian (2021)

Gambar 10

Halaman laporan pengeluaran proyek

c. Halaman data barang 
g. Halaman status laporan pengeluaran proyek

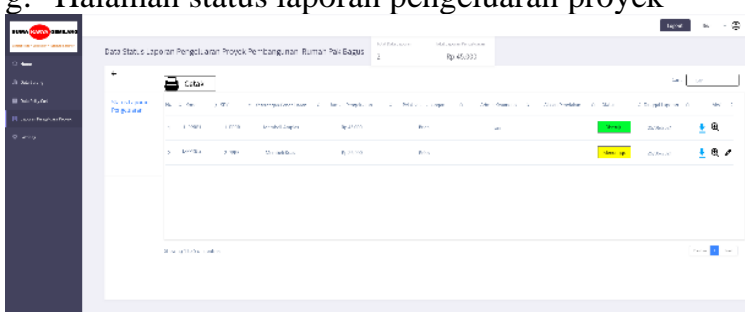

Sumber : Penelitian (2021)

Gambar 11

Halaman status laporan pengeluaran proyek

h. Halaman mengubah nama dan foto
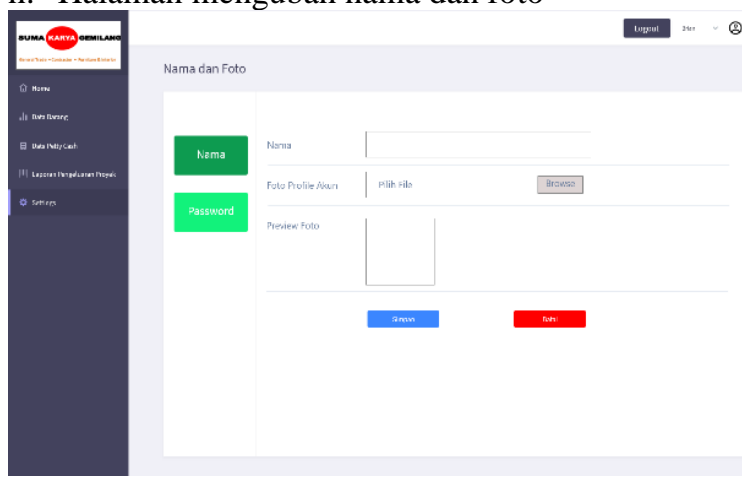

Sumber : Penelitian (2021)

Gambar 12

Halaman mengubah nama dan foto

i. Halaman mengubah password

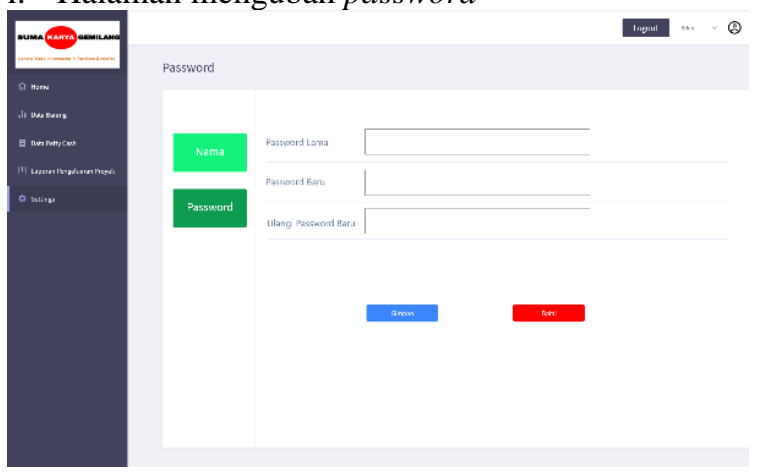

Sumber : Penelitian (2021)

Gambar 13

Halaman mengubah password

\section{Pengujian}

a. Pengujian front-end

Pengujian antarmuka pada front-end dilakukan oleh calon pengguna front-end. Dalam pengujian ini dilakukan oleh pengguna.

\section{Tabel 1}

Hasil pengujian front-end

\begin{tabular}{cccccccccc}
\hline Partisipan & $\begin{array}{c}\text { Akses } \\
\text { Menu }\end{array}$ & $\begin{array}{c}\text { Input } \\
\text { Barang }\end{array}$ & $\begin{array}{c}\text { Input } \\
\text { Petty } \\
\text { Cash }\end{array}$ & $\begin{array}{c}\text { Input Laporan } \\
\text { Pengeluaran } \\
\text { Proyek }\end{array}$ & $\begin{array}{c}\text { Input } \\
\text { Akun }\end{array}$ & $\begin{array}{c}\text { Edit } \\
\text { Akun }\end{array}$ & Login Logout \\
\hline 1 & $\checkmark$ & $\checkmark$ & $\checkmark$ & $\checkmark$ & $\checkmark$ & $\checkmark$ & $\checkmark$ & $\checkmark$ \\
\hline 2 & $\checkmark$ & $\checkmark$ & $\checkmark$ & $\checkmark$ & $\checkmark$ & $\checkmark$ & $\checkmark$ & $\checkmark$ \\
\hline 3 & $\checkmark$ & $\checkmark$ & $\checkmark$ & $\checkmark$ & $\checkmark$ & $\checkmark$ & $\checkmark$ & $\checkmark$ \\
\hline 4 & $\checkmark$ & $\checkmark$ & $\checkmark$ & $\checkmark$ & $\checkmark$ & $\checkmark$ & $\checkmark$ & $\checkmark$
\end{tabular}

\begin{tabular}{lcccccccc}
\hline \multicolumn{1}{c}{5} & $\checkmark$ & $\checkmark$ & $\checkmark$ & $\checkmark$ & $\checkmark$ & $\checkmark$ & $\checkmark$ & $\checkmark$ \\
\hline Sukses & 5 & 5 & 5 & 5 & 5 & 5 & 5 & 5 \\
\hline $\begin{array}{l}\text { Nilai } \\
\text { Kesuksesan }\end{array}$ & $100 \%$ & $100 \%$ & $100 \%$ & $100 \%$ & $100 \%$ & $100 \%$ & $100 \%$ & $100 \%$
\end{tabular}

Sumber : Penelitian (2021)

b. Pengujian back-end

Pengujian antarmuka pada back-end dilakukan oleh calon pengguna back-end. Dalam pengujian ini dilakukan oleh calon administrator web.

Tabel 2

Hasil pengujian back-end

\begin{tabular}{cccccccccc}
\hline Partisipan & $\begin{array}{c}\text { Akses } \\
\text { Menu }\end{array}$ & $\begin{array}{c}\text { Input } \\
\text { Barang }\end{array}$ & $\begin{array}{c}\text { Input } \\
\text { Petty } \\
\text { Cash }\end{array}$ & $\begin{array}{c}\text { Input Laporan } \\
\text { Pengeluaran } \\
\text { Proyek }\end{array}$ & $\begin{array}{c}\text { Input } \\
\text { Akun }\end{array}$ & $\begin{array}{r}\text { Edit } \\
\text { Akun }\end{array}$ & Login Logout \\
\hline 1 & $\checkmark$ & $\checkmark$ & $\checkmark$ & $\checkmark$ & $\checkmark$ & $\checkmark$ & $\checkmark$ & $\checkmark$ \\
\hline 2 & $\checkmark$ & $\checkmark$ & $\checkmark$ & $\checkmark$ & $\checkmark$ & $\checkmark$ & $\checkmark$ & $\checkmark$ \\
\hline 3 & $\checkmark$ & $\checkmark$ & $\checkmark$ & $\checkmark$ & $\checkmark$ & $\checkmark$ & $\checkmark$ & $\checkmark$ \\
\hline 4 & $\checkmark$ & $\checkmark$ & $\checkmark$ & $\checkmark$ & $\checkmark$ & $\checkmark$ & $\checkmark$ & $\checkmark$ \\
\hline 5 & $\checkmark$ & $\checkmark$ & $\checkmark$ & $\checkmark$ & $\checkmark$ & $\checkmark$ & $\checkmark$ & $\checkmark$ \\
\hline Sukses & 5 & 5 & 5 & 5 & 5 & 5 & 5 & 5 \\
\hline $\begin{array}{l}\text { Nilai } \\
\text { Kesuksesan }\end{array}$ & $100 \%$ & $100 \%$ & $100 \%$ & $100 \%$ & $100 \%$ & $100 \%$ & $100 \%$ & $100 \%$
\end{tabular}

Sumber : Penelitian (2021)

\section{KESIMPULAN}

Dengan adanya sistem ini mampu memberikan hasil yang positif dan efisien. Perubahan dari sistem yang belum terkomputerisasi menjadi sistem yang sudah terkomputerisasi memberikan dampak yang cukup signifikan diantaranya, Dengan rancangan sistem ini penyimpanan dokumen menjadi lebih teratur dan dapat mengurangi tumpukan dokumen, dengan adanya sistem ini juga dapat meningkatkan kinerja perusahaan karena perusahaan dapat mengontrol setiap data yang masuk seperti laporan pengajuan dana dan laporan pengeluaran proyek, dapat mengurangi kesalahan dalam pembuatan laporan, karena proses pembuatan laporan sudah terkomputerisasi sehingga mendapatkan sebuah laporan yang memberikan informasi yang cepat, tepat dan akurat.

\section{REFERENSI}

Abdulloh, R. (2018). 7 in 1 Pemrograman Web untuk Pemula. Elex Media Komputindo.

Andrianto, P., \& Nursikuwagus, A. (2017). Sistem Informasi Pelayanan Kesehatan Berbasis Web di Puskesmas. Jurnal Prosiding Seminar Nasional Komputer Dan Informatika (SENASKI), 1(2), 47-52.

Durahman, N., \& Karma, M. (2018). Sistem Informaso E-Commerce Pada Toko ArRumaitsah Collection Berbasis Php Bootstrap. Jurnal Manajemen Informatika, 5(2), 46-52. 
Lesmana, H., Erawati, W., Mubarok, H., \& Suryanti, E. (2020). Implementasi ABSS Accounting Pada Laporan Keuangan CV One Solution Media. 5, 166-180.

Marisa, F. (2017). Web Programming (Client Side and Server Side). Deepublish.

Rani, H. A. (2016). Manajemen Proyek Konstruksi. Deepublish.

Refun, Z., Suryanto, I., \& Sapulette, W. (2017). Analisa Cost Overruns pada Beberapa Proyek Konstruksi di Kota Ambon. Jurnal Manumata: Jurnal Ilmu Teknik, 3(1), 26-34.

Sari, A. O., Abdilah, A., \& Sunarti. (2019). Web Programming. Graha Ilmu.

Simanjuntak, M. R. A., \& Baskoro, A. T. (2020). Kajian Faktor - Faktor Manajemen Pembiayaan Proyek Dalam Implementasi Bim Pada Proyek Bangunan Gedung. Seminar Nasional Inovasi Teknologi Terapan, 4(12), 411-416.

Sitanggang, N., Simarmata, J., \& Luthan, P. L. A. (2019). Pengantar Konsep Manajemen Proyek untuk Teknik. Yayasan Kita Menulis.

Sukamto, R. A., \& Shalahuddin, M. (2019). Rekayasa Perangkat Lunak Terstruktur dan Berorientasi Objek. Informatika. 